\title{
Conflict Activity Styles of Psychological Counsellor Candidates: A Study of Based on Forgiveness and Psychological Well-Being
}

\author{
Durmuş Ümmet ${ }^{1, *}$ \\ ${ }^{1}$ Department of Psychological Counseling and Guidance, Marmara University, Turkey \\ *Correspondence: Marmara University, Atatürk Eğitim Fakültesi, Eğitim Bilimleri Bölümü, Göztepe, Kadıköy, \\ 34722, Istanbul, Turkey. E-mail: dummet@marmara.edu.tr
}

Received: June 26, 2020

Accepted: July 21, $2020 \quad$ Online Published: Augusut 18, 2020

doi:10.5430/wje.v10n4p35

URL: https://doi.org/10.5430/wje.v10n4p35

\begin{abstract}
The purpose of this study is to assess the conflict activity styles of psychological counselor candidates in terms of psychological well-being and forgiveness. The sample of the study consists of a total of 410 individuals, 281 females and 129 males, who are studying at the department of psychological counseling and guidance at 4 different universities located at İstanbul during the 2019-2020 academic year. The study data were collected by "Personal information form", "Conflict activity styles scale", "Forgivingness scale" and "Psychological well-being scale". The data was analyzed with SPSS-21 statistic software program. The first step of the data analysis included the assessment of the relationship between the variables with Pearson correlation analysis, which then followed by hierarchical multiple regression analysis in order to evaluate the psychological well-being and forgivingness as mutual predictors of conflict styles. The obtained results showed that there is a significant correlation between the psychological counselor candidates' conflict style scores and their psychological well-being and forgivingness scores. Additionally, it was found that these two variables, though in different percentages, are predictor variables of conflict activity styles of psychological counselors. The data were discussed considering the literature to lead variety of suggestions which would serve both the researchers and field practitioners.
\end{abstract}

Keywords: conflict activity styles, psychological well-being, forgivingness, candidate psychological counselor

\section{Introduction}

Everyone frequently faces with situations of conflict as a natural cause of one's daily and professional life. Conflict is unavoidable in cases of divergence, as well as when desires and wishes do not match or when there is a shift in personal expectations. Actually, as can be seen in these examples, conflict should not always be treated as a negative fact since it is inherent in life. The main focus should be on the management of the conflict process by the individual in concern. Conflict is a concept in which mutually related subjects are tried to be defined from diverse perspectives. Conflict can be defined as the rivalry of power and status generating from divergence among people involved in an action concerning more than one person. Furthermore, conflict, mostly initiated among individuals due to unfulfilled needs, limited resources, and differences in acquired values, is addressed as the behavioral action and attitude display process mutually carried out by the involved parties to resolve the current dispute and to achieve remedy and agreement for the raised issues (Deutsch, 1973; Jandt \& Pedersen, 1996; Johnson \& Johnson, 2003; Karip, 2013; Wall \& Callister, 1995). Nonetheless, positive aspects of the conflict, such as enabling an individual to generate diverse strategies to deal with the issue, thus increasing both productivity and self-respect, should also be taken into account. On the other hand, it is also stated that conflict initiates feelings of anger, hatred, grunge, thus considered to be a risk for mental health disorders (Öksüz and Öztürk, 2016). It seems that individuals have diverse management styles of conflict process.

There are other studies in the literature that categorize conflict activity styles differently. When explaining the sub-dimension of their scale, which is also used in this study, Karadağ and Tosun (2014) defined the conflict activity styles as follows: Avoidant style; withdraws from conflict, abandoning both relations and personal objectives, coercive style; prioritizes personal objectives over relations and would do anything to win in a conflict situation, facilitator style; avoids conflict situations caring more about relations rather than personal objectives, mediator style; considers both relations and personal objectives as important trying to find an intermediate solution. Last is the 
contestatory style where neither relations nor objectives are abandoned, and the involved parties are all focused on maximum gain. Considering the definitions, mediator and contestatory styles can be evaluated as positive styles in conflicting situations whereas avoidant, coercive, and facilitator styles are negative. Thomas (1976) identified five conflict resolution method based on assertiveness and cooperativeness aspects of conflict styles. The assertiveness aspect covers behaviors addressed to satisfy one's self desires/objectives and anxieties, whereas the cooperativeness aspect covers behaviors addressed to satisfy someone else's desires/objectives and anxieties. When evaluated in this respect, conflict styles of competing, collaborating, mediator, avoiding, and accommodating are identified. Furthermore, Rusbult and Zembrodt (1983) mentioned four conflict styles as exit, voice, loyalty, and neglect. Exit contains active and destructive behavior patterns such as ending the relationship. Voice consists of active but constructive behavior such as resolving discussions and getting professional help. Loyalty contains passive but constructive behavior such as praying for a resolution or hoping for spontaneous recovery. Last, neglect consists of passive but destructive behavior such as avoiding discussing the problem or ignoring the partner. Based on these explanations, it is clear that individuals have different ways to conduct conflict situations and we can also think that there are other personal or relation-based factors that influence these differences.

One individual variable that may lead a diversity in the conflict styles can be argued to be personal psychological well-being. The psychological well-being concept is one of the concepts that positive psychology, a field raised prominence in the last decades, has been working on (Matsumoto, 2009). Psychological well-being is an individual concept focusing on self-improvement and self-realization. Additionally, the concept of psychological well-being emphasizes a lifestyle where mankind, a multi-dimensional structure, is considered to be a whole and self-responsible to protect, sustain and develop its wellness within this whole. Furthermore, individuals with high psychological well-being are more satisfied with life (Kahneman, 1999; Keyes, Shmotkin \& Ryff, 2002; Ryff \& Keyes, 1995; Ryff \& Singer, 2008). Experts define six aspects of psychological well-being as; self-acceptance, purpose in life, autonomy, positive relations with others, environmental mastery and personal growth (Ryan \&Deci, 2001; Ryff \& Keyes, 1995). Although all of these can be related to an individual's conflict situation with others, 'positive relations with others' aspect require special attention. When explaining this aspect of psychological wellbeing, Ryff (1898) emphasizes the ability to establish close and warm relationships with others. Feeling love for others is considered to be very important in terms of mental health and self-improvement. Additionally, this aspect is taken as a sign of maturity. Hence, individuals with a higher level of psychological well-being are expected to employ more successful styles for managing conflicts with others.

Another variable that may lead to a diversity in the individual conflict styles is considered to be forgivingness, a concept related to personal relationships. Forgivingness is a concept of high importance in positive psychology with respect to its power, when executed as forgiving someone, to establish positive thoughts, feelings, and attitudes towards the guilty party and to encourage the continuity of social relationships (Harris et al., 2006; Toussaint et al., 2008). Forgivingness is an inner process since it contains inner change towards an offender in terms of interpersonal perception. In other words, the forgiving party goes through an inner change of thoughts, feelings, drives and behavior in case the offender is forgiven. Additionally, forgivingness carries an interpersonal touch since it arises when there is an infringement in the relationship and involves an individual forgiving the other one (Asic1, 2018; McCullough et. Al., 2000). There are studies which show individual personality characteristics, compensative behavior of the other party and the level of harm subject to forgiveness are all components of the forgivingness action (Brown, 2004; Bugay \& Demir; 2011). Definition of forgivingness in terms of motivational change in interpersonal relations reflects a decrease in the individual's feelings of revenge and alienation towards the accused person and an increase in reconciliation motivation. The common point within various forgivingness definitions is the fact that the feelings of the forgiving party towards the forgiven have become less negative (hatred, anger and urge of revenge) and more positive (empathy, affection, compassion) (McCullough et. al, 1997). Interpersonal forgivingness has been defined: "injured party's free-willed refusal of hurting the other party and not only freeing one's self of the negative feelings but also trying to initiate positive feelings for the other party despite all the disagreements, disputes and mutual destructive behavior as the ultimate outcome of these" (Kaya, 2019). As can be seen from all these explanations, individual forgiveness provides the use of more successful styles for managing conflicts with others.

Previous studies indicate that the aforementioned variables (conflict activity styles, psychological well-being and forgivingness) are interrelated but to our knowledge there is not any study which discusses all of them. It is considered to be important for psychological counselors to have a personal successful conflict style throughout their professional conduct. Especially they might need it while exercising self-disclosure method, giving examples from their own life for the sake of establishing a successful relationship with their clients. This is why this study was 
performed with psychological counselor candidates believing that findings of the study would guide the studies conducted by the academicians who teach psychological counselors. Throughout the psychological counselor education, especially both in course content and during the out-of-class events, it would be highly beneficial to discuss forgiveness and psychological well-being of psychological counselor candidates, consequently emphasizing the conflict styles. Within this framework, we believe that this study would contribute to the experts working in the guidance and psychological counseling field, especially in terms of psychological counselor training. Thus qualified school psychological counselors will increase the quality of education in the schools where they will work in the future. In this context the purpose of the study is to appraise the impact of psychological well-being and forgivingness of psychological counselor candidates on their conflict activity style. Based on this primary purpose, answers to the following questions were sought throughout the study:

(1) Is there a significant correlation between the conflict activity style score of the psychological counselor candidates and their psychological well-being and forgivingness scores?

(2) Do the psychological well-being and forgivingness scores of psychological counselor candidates are significant predictors of different conflict styles (facilitator, mediator, coercive, contestatory, and avoidant)?

\section{Method}

\subsection{Research Design}

This research is a relational survey model study prepared to evaluate the conflict activity styles of psychological counselor candidates in terms of psychological well-being and forgivingness. Relational survey model is a statistical method used for determining the existence and degree of a relationship between one or more variables (Creswell, 2012).

\subsection{Participants}

The sampling of the study consists of a total of 410 students, 281 female and 129 males, in between the ages of 18-26 (mean $=21,54)$, who are studying in the psychological counseling and guidance department of 4 separate universities, 2 public ( $\mathrm{n}=310), 2$ private $(\mathrm{n}=100)$ in the city of İstanbul. 94 of the students attend 1st year, 108 to 2 nd year, 111 to 3 rd year and 97 to 4 th year. Sampling group is configured by accessible convenience sampling method where the convenience sampling method is when samples are selected from accessible and applicable units due to time, money and labor limitations (Büyüköztürk, 2012).

\subsection{Data Collection Tools}

In order to collect data, Personal Information Form (PIF), Conflict Activity Styles Inventory, Psychological well-being scale and Forgivingness Scale were applied to the participants.

\subsubsection{Personal Information Form}

In order to collect demographic information about participants, a personal information form was developed by the researcher including questions about gender, age, university type, and grade level.

\subsubsection{Conflict Activity Styles Inventory}

The original of the conflict activity styles scale is developed by Johnson \& Johnson (2008) and was adapted to Turkish culture by Karadağ \& Tosun (2014). Conflict Activity Style Scale is designed to determine the actional movement manner adapted by the individual in order to cope with the conflict state. Item discrimination, validity and reliability analysis of the scale items were conducted over a study of 241 university students. Chi-square $(\chi 2)$ value and statistical significance level fit for the model created in the confirmatory factor analysis $[\chi 2=197.21, \mathrm{sd}=138]$ as the construct reliability study of the scale, were defined. Other goodness of fit indexes of the model [GFI $=0.91$, AGFI $=0.88$, RMSEA=0.05] shows that the proposed model is appropriate. Furthermore, load factor value of confirmatory factor analysis is between 0.47 and 0.83 . Scale has a structure of 5 sub-scales and the Cronbach Alpha values of these are calculated as; .77 for the facilitator, .78 for the mediator, .76 for coercive, .76 for contestatory and .79 for avoidant. For this specific study the Cronbach Alpha values are recalculated and the values are; .68 for the facilitator, .71 for the mediator, .65 for coercive, .70 for contestatory and .71 for avoidant.

\subsubsection{Forgivingness Scale}

In order to access the forgiveness level of individuals, Sarıçam \& Akın (2013) adapted the Forgiveness Scale which was originally developed by Berry, Worthington, O'Connor, Parrott III, \& Wade (2004), into Turkish. It is a 10-item Likert scale where the lowest point one can get is 10 and the highest is 50 . As a result of the exploratory factor 
analysis, KMO sampling adequacy coefficient is found as 66.6 and Barlett test $\chi^{2}$ value as $518,353(\mathrm{p}<.001$, sd=120). Confirmatory factor analysis done as the construct reliability of the scale, show 10 items as fit in single dimension $\left(\mathrm{x}^{2}=106.47, \mathrm{sd}=32, \mathrm{RMSEA}=.077, \mathrm{CFI}=.89, \mathrm{GFI}=.95, \mathrm{AGFI}=.91, \mathrm{SRMR}=.062\right)$, consistent with the original form. The load factor of the scale is ranged between .52 and .77 and the Cronbach Alfa internal consistency reliability coefficient is found to be .67 . Criterion validity study showed that there is a positive $(\mathrm{r}=.84)$ correlation between forgivingness and Heartland forgiving and also a positive $(\mathrm{r}=.52)$ correlation between forgivingness and modesty. Test-retest correlation coefficient is found to be .88 for the whole scale and corrected item-total correlations are ranked between .37 and .48. Cronbach Alpha value for this study is calculated as .78 .

\subsubsection{Psychological Well-Being Scale}

Psychological well-being scale is developed by Diener et al. (2009-2010) and adapted to Turkish by Telef (2013). Scale has been developed to define the individual's psychological well-being and to carry out the task of completing existing measurement tools. The scale has 8 items where all items are positive, and the lowest total grade is 8 and the highest is 56. It is a single dimension. The high grading of the scale means that the individual has access to psychological resources and strength. The scale does not measure distinct levels of well-being but gives an overall idea about the positive functionality of the major subjects. Cronbach's alpha internal consistency coefficient is found to be .80 as a result of the Psychological Well-Being Scale reliability study. With respect to the test-retest results, a positive significant high correlation was obtained between the first and second application of the scale test. The total item correlation of the scale showed alteration between .41 and .63 and $t$ value was found to be significant. Cronbach's Alpha internal correlation coefficient in this study is found to be .82 .

\subsection{Data Analysis}

Participation to the study was done on voluntary basis where all participants were informed about the scope and method of the study and all applications were done within means of privacy. The data of the research were collected between 14-30 October 2019. All participants voluntarily participated in the study and their identity information was kept confidential. An informed consent form was placed on the front page of the data collection tools. Participants read and signed this consent form before answering the scales. Data was processed with SPSS 21 software using a computer. Pearson product-moment correlation coefficient was employed for relationship between conflict activity styles sub-dimensions and psychological wellbeing and forgivingness whereas hierarchical multiple regression was employed for psychological well-being and forgivingness as predictors of conflict activity style.

\section{Results}

In this section, statistical analysis findings of study data are given in tables

Table 1. Minimum-Maximum Values, Arithmetic Mean and Standard Deviation Value of Variables

\begin{tabular}{lccccc}
\hline & $\mathrm{N}$ & Min & Max & Mean & SD \\
\hline Psychological well-being & 410 & 21,00 & 54,00 & 43,38 & 5,87 \\
Forgivingness & 410 & 13,00 & 48,00 & 31,86 & 6,39 \\
Facilitator Style & 410 & 12,00 & 33,00 & 25,22 & 3,55 \\
Mediator Style & 410 & 12,00 & 35,00 & 25,00 & 3,93 \\
Coercive Style & 410 & 9,00 & 29,00 & 18,59 & 3,38 \\
Contestatory Style & 410 & 10,00 & 30,00 & 20,02 & 3,70 \\
Avoidant Style & 410 & 8,00 & 25,00 & 17,01 & 3,51 \\
\hline
\end{tabular}

Table 1 shows the descriptive statistical values of the gradings of the dependent and independent variables. The means of gradings for Psychological Well-Being Scale is 43, 38. Forgivingness Scale is 31, 86 and Subscales of Conflict Activity Styles Scale; Facilitator is 18, 59, Mediator is 25, 00, Coercive is 25, 22, Contestatory is 20, 02 and Avoidant is 17, 01 respectively. 
Table 2. Pearson Correlation Coefficients of the Variables

\begin{tabular}{lccccccc}
\hline Variables & 1 & 2 & 3 & 4 & 5 & 6 & 7 \\
\hline 1. Psychological well-being & 1 &, $338^{*}$ &, $562^{*}$ &, $426^{*}$ &,$- 307^{*}$ &, $267^{*}$ &,- 035 \\
2. Forgivingness & & 1 &, $301^{*}$ &, $231^{*}$ &,$- 170^{*}$ &, $163^{*}$ &,$- 144^{*}$ \\
3. Facilitator Style & & & 1 &, $573^{*}$ &,$- 461^{*}$ &, $425^{*}$ &,$- 219^{*}$ \\
4. Mediator Style & & & & 1 &,$- 387^{*}$ &, $498^{*}$ &,$- 239^{*}$ \\
5. Coercive Style & & & & & 1 &,$- 406^{*}$ &, $298^{*}$ \\
6. Contestatory Style & & & & & & &,- 077 \\
7. Avoidant Style & & & & & & 1 & \\
\hline
\end{tabular}

${ }^{*}: \mathrm{P}<.01$

Table 2 shows a positive significant correlation between facilitator conflict style grading and gradings of psychological well-being $(\mathrm{r}=.562 ; \mathrm{p}<.050)$ and forgivingness $(\mathrm{r}=.301 ; \mathrm{p}<.050)$. There is a positive significant correlation between mediator conflict style grading and gradings of psychological well-being $(\mathrm{r}=.426 ; \mathrm{p}<.050)$ and forgivingness $(\mathrm{r}=.231 ; \mathrm{p}<.050)$. There is a negative significant correlation between coercive conflict style grading and gradings of psychological well-being $(\mathrm{r}=-.307 ; \mathrm{p}<.050)$ and forgivingness $(\mathrm{r}=-.170 ; \mathrm{p}<.050)$. There is a positive significant correlation between contestatory conflict style grading and gradings of psychological well-being ( $\mathrm{r}=.267$; $\mathrm{p}<.050)$ and forgivingness $(\mathrm{r}=.163 ; \mathrm{p}<.050)$. Last, the correlation between avoidant conflict style grading and psychological well-being grading $(\mathrm{r}=.035 ; \mathrm{p}>.050)$ is not significant but the avoidant conflict style grading and forgivingness grading $(\mathrm{r}=.144 ; \mathrm{p}<.050)$ have a negative significant correlation.

Table 3. Hierarchical Regression Analysis for Psychological Well-Being and Forgivingness as Predictors of Facilitator Conflict Style

\begin{tabular}{llcccccc}
\hline \multirow{2}{*}{ Predictor Variables } & \multicolumn{5}{c}{ Facilitator Conflict Style } \\
\hline \multirow{2}{*}{ Step 1 } & Psychological well-being & .316 & .316 & .562 & 13.716 & $188.131^{*}$ \\
\multirow{2}{*}{ Step 2 } & Psychological well-being & .330 & .014 & .519 & 12.041 & $100.038^{*}$ \\
\hline & Forgivingness & & & .126 & 2.914 & 10 \\
\hline
\end{tabular}

$*: \mathrm{P}<.01$

Results of the regression analysis show that psychological well-being gradings are predicting the facilitator conflict style gradings of the psychological counselor candidates at a significant level $(\mathrm{F}=188.131 ; \mathrm{p}<.001)$. Results of the hierarchical multiple regression show that psychological well-being gradings and forgivingness gradings together are predicting the facilitator conflict style gradings at a statistically significant level $(\mathrm{F}=100.038 ; \mathrm{p}<.001)$. Psychological well-being grading explains $32 \%$ of the total variance by itself at the first stage and $33 \%$ of the total variance together with the forgivingness gradings at the second stage.

Table 4. Hierarchical Regression Analysis for Psychological Well-Being and Forgivingness as Predictors of Mediator Conflict Style

\begin{tabular}{|c|c|c|c|c|c|c|}
\hline \multirow{2}{*}{\multicolumn{2}{|c|}{ Predictor Variables }} & \multicolumn{5}{|c|}{ Mediator Conflict Style } \\
\hline & & $R^{2}$ & $R^{2}$ change & $\beta$ & $t$ & $F$ \\
\hline Step 1 & Psychological well-being & .180 & .182 & .426 & 9.516 & $90.553^{*}$ \\
\hline Step 2 & $\begin{array}{l}\text { Psychological well-being } \\
\text { Forgivingness }\end{array}$ & .186 & .009 & $\begin{array}{l}.393 \\
.098\end{array}$ & $\begin{array}{l}8.289 \\
2.077\end{array}$ & $47.800^{*}$ \\
\hline
\end{tabular}

$*: \mathrm{P}<.01$

Results of the regression analysis show that psychological well-being gradings are predicting the mediator conflict style gradings of the psychological counselor candidates at a significant level $(\mathrm{F}=90.553 ; \mathrm{p}<.001)$. Results of the hierarchical multiple regression show that psychological well-being gradings and forgivingness gradings together are predicting the mediator conflict style gradings at a statistically significant level $(\mathrm{F}=47.800 ; \mathrm{p}<.001)$. Psychological well-being grading explains $18 \%$ of the total variance by itself at the first stage and $19 \%$ of the total variance together with the forgivingness gradings at the second stage. 
Table 5. Hierarchical Regression Analysis for Psychological Well-Being and Forgivingness as Predictors of Coercive Conflict Style

\begin{tabular}{llccccc}
\hline \multirow{2}{*}{ Predictor Variables } & \multicolumn{5}{c}{ Coercive Conflict Style } \\
\cline { 3 - 7 } & & $R^{2}$ & $R^{2}$ change & $\beta$ & $t$ & $F$ \\
\hline \multirow{2}{*}{ Step 1 } & Psychological well-being & .094 & .094 & -.307 & -6.523 & $42.556^{*}$ \\
\multirow{2}{*}{ Step 2 } & Psychological well-being & .179 & .084 & -.412 & -8.627 & $44.331^{*}$ \\
\hline
\end{tabular}

*: $\mathrm{P}<.01$

Results of the regression analysis show that psychological well-being gradings are predicting the coercive conflict style gradings of the psychological counselor candidates at a significant level $(F=42.556 ; p<.001)$. Results of the hierarchical multiple regression show that psychological well-being gradings and forgivingness gradings together are predicting the coercive conflict style gradings at a statistically significant level $(\mathrm{F}=44.331 ; \mathrm{p}<.001)$. Psychological well-being grading explains $9 \%$ of the total variance by itself at the first stage and $18 \%$ of the total variance together with the forgivingness gradings at the second stage.

Table 6. Hierarchical Regression Analysis for Psychological Well-Being and Forgivingness as Predictors of Contestatory Conflict Style

\begin{tabular}{llccccc}
\hline \multirow{2}{*}{ Predictor Variables } & \multicolumn{5}{c}{ Contestatory Conflict Style } \\
\cline { 3 - 7 } & & $R^{2}$ & $R^{2}$ change & $\beta$ & $t$ & $F$ \\
\hline \multirow{2}{*}{ Step 1 } & Psychological well-being & .071 & .071 & .267 & 5.592 & $31.271^{*}$ \\
\multirow{2}{*}{ Step 2 } & Psychological well-being & .077 & .006 & .239 & 4.724 & $17.016^{*}$ \\
\hline & Forgivingness & & & .082 & 1.624 & ${ }^{*}$ \\
\hline
\end{tabular}

${ }^{*}: \mathrm{P}<.01$

Results of the regression analysis show that psychological well-being gradings are predicting the contestatory conflict style gradings of the psychological counselor candidates at a significant level ( $\mathrm{F}=31.271 ; \mathrm{p}<.001)$. Results of the hierarchical multiple regression show that psychological well-being gradings and forgivingness gradings together are predicting the contestatory conflict style gradings at a statistically significant level $(\mathrm{F}=17.016 ; \mathrm{p}<.001)$. Psychological well-being grading explains $7 \%$ of the total variance by itself at the first stage and $8 \%$ of the total variance together with the forgivingness gradings at the second stage.

Table 7. Hierarchical Regression Analysis for Psychological Well-Being and Forgivingness as Predictors of Avoidant Conflict Style

\begin{tabular}{llccccc}
\hline \multirow{2}{*}{ Predictor Variables } & \multicolumn{5}{c}{ Avoidant Conflict Style } \\
\cline { 3 - 7 } & & $R^{2}$ & $R^{2}$ change & $\beta$ & $t$ & $F$ \\
\hline \multirow{2}{*}{ Step 1 } & Psychological well-being & .001 & .001 & -.035 & -.715 & .511 \\
\multirow{2}{*}{ Step 2 } & Psychological well-being & .021 & .020 & .015 & .290 & \multirow{2}{*}{$4.367^{*}$} \\
\hline
\end{tabular}

*: $\mathrm{P}<.01$

Results of the regression analysis show that psychological well-being gradings are not predicting the avoidant conflict style gradings of the psychological counselor candidates $(\mathrm{F}=.511 ; \mathrm{p}<.050)$. Results of the hierarchical multiple regression show that psychological well-being gradings and forgivingness gradings together are predicting the coercive conflict style gradings at a statistically significant level $(\mathrm{F}=4.367 ; \mathrm{p}<.050)$. Psychological well-being grading does not significantly explain the total variance by itself at the first stage but do explain $2 \%$ of the total variance together with the forgivingness gradings at the second stage.

\section{Discussion}

When the statistical analyses are evaluated, we can see a positive significant correlation between the scores of facilitator, mediator, and contestatory conflict styles and scores of psychological well-being and forgivingness. However, there is a negative significant correlation between the scores of coercive and avoidant conflict styles and scores of psychological well-being and forgivingness. Based on these findings, scores of facilitator, mediator, and 
contestatory conflict styles of the psychological counselor candidates rise as their psychological well-being and forgivingness increase whereas, their gradings of coercive and avoidant conflict styles fall. Based on the findings of the study, psychological well-being and forgivingness scores, together, predict the facilitator conflict style scores at a statistically significant level, hence both psychological well-being and forgivingness are important variables in facilitator conflict style. When literature is reviewed, facilitator style is not considered to be a successful conflict style. Taking into account the scale used in this study, the items employed for the measurement of this sub-dimension is known to measure the individual's refrain from the conflict by abandoning personal objectives for the sake of saving relations (Karadağ \& Tosun, 2014). However, findings indicate a positive correlation between psychological well-being and forgivingness and facilitator conflict style which may be justified through a cultural point of view. Contrary to autonomous self, relational self is more prominent in collectivist-cultured Turkish society (Kağıtçıbaşı, 1996). Individuals cherish their relations in relational self, whereas autonomous self prioritizes independence and personal objectives, in other words, relations are much more important than personal objectives in relational self (Kağıtçıbaşı, 2005). Even though autonomous self is more related with psychological well-being in Western cultures, it is quite the contrary in communitarian cultures like Turkey. (i.e., Freeman, 1997; Özdemir, 2012; Yeh \& Yang, 2006). Based on this perspective, it can be concluded that a positive correlation between facilitator conflict style and psychological well-being and forgivingness is an anticipated finding in this study that carries the features of the host culture.

As a result of the study, it was found that psychological well-being and forgivingness scores of psychological counselor candidates, together, are predicting both mediator and contestatory conflict styles at a significant level. As indicated before, mediator and contestatory conflict styles are successful manners and psychological well-being of individuals which is an efficient variable in using healthier conflict styles can be considered to be an expected finding. The pioneer of psychological well-being researches, Ryff (1989) defines the close and warm relationships of an individual with others as an aspect of psychological well-being, hence one can expect individuals with higher psychological well-being to apply a healthier conflict manner when dealing with others. In a study conducted with teacher candidates, İkiz and Çatal (2019) found positive correlation between positive conflict activity styles and self-efficacy perception which may be a relevant psychological well-being concept. Furthermore, Akdoğan and Yalçın (2018) found a negative correlation between well-being of high school students and their contestatory conflict styles and a similarly negative correlation between well-being of high school students with their mediator conflict styles. Limited amount of study show that psychological well-being is an efficient variable in individual's conflict style. The positive effect of forgivingness on individual's choice of successful conflict styles can be considered as an anticipated finding. Hence, we can claim that elevated level of forgiving manner plays an important role in conflicts by facilitating the increase in positive thoughts, feelings and behavior towards the other party and playing a role in continuity of social relations (Harris et. Al, 2006; Toussaint et al., 2008). Enright et al. (1996) defines forgivingness as individual's voluntary renouncement of negative feelings, thoughts, and behaviors such as anger, revenge and ignorance towards the person who has caused harm and subsequent inner sprouting of positive feelings like compassion, generosity and affection. The common point of all forgivingness definitions is that forgiving person's feelings toward the forgiven person become less negative (McCullough et al., 1997). Therefore, individuals will develop more mediator and contestatory conflict activities in conflicting situations as they forgive more.

Based on the findings of the study, psychological well-being and forgivingness scores, together, predict the coercive conflict style scores at a statistically significant level. As the last finding of the study, psychological well-being of psychological counselor candidates does not predict the avoidant conflict style scores, but forgivingness predicts this conflict style. These findings indicate that individuals with low psychological well-being tend to employ more negative conflict styles. As a supporting finding, Söner and Yllmaz (2018) claim that there is a negative significant correlation between individual's psychological well-being and negative conflict situations they experience in virtual environments. Forgivingness which is a more efficient variable in avoidance conflict styles can be related to the impact of fostered feelings of the individual towards the conflicting person or situation, that is, a person can experience more than one feeling throughout the conflict process and forgivingness characteristic of that person is one of the factors that affect these feelings. For the sake of supporting the idea of forgivingness as an important variable of the avoidant conflict style, McCullought et al., (2000), in their definition where forgivingness is considered as an interpersonal concept, emphasize that interpersonal motivation of the forgiving individual socially improve, which in turn enable the individual to be more helpful, less vindictive and less timid. Forgivingness does not only have a positive impact on individuals but also on society and social well-being. Interpersonal forgivingness is considered as a prosocial behavior and contributes to the togetherness with the valued people, as well as the continuity of social support (Karremans \&Van Lange, 2004). When all arguments are taken into account, we can 
conclude that forgivingness is an efficient variable of individual conflict style.

Based on the findings of the study, positive impact of the psychological well-being and forgivingness on the facilitator conflict style of the psychological counselor candidates can be seen. The facilitator conflict style is a negative style with an action of abandoning the conflicting situation. The finding has been assessed in terms of cultural specifications, but it is important to conduct further qualitative studies in order to get a better understanding. Furthermore, there were no studies conducted on conflict activity styles of psychological counselor candidates, hence, it would be highly beneficial to conduct further studies on this subject with diverse variables in order to enhance the field and contribute positively to other studies done with psychological counselors. The main finding of the study is that both psychological well-being and forgivingness of the psychological counselor candidates have a positive relation with successful conflict styles and negative relation with unsuccessful ones. From this finding forth, actions can be planned to increase the well-being of psychological counselor candidates and to improve their forgivingness characteristics. The findings can be used in organizing program contents and education policy making in higher education institutions. However, there are some limitations. This study was conducted with psychological counselor candidates studying in universities located in İstanbul. It would be highly recommended to conduct similar studies with students from universities of diverse locations. Furthermore, there were no records of previous studies conducted directly with psychological counselor candidates, thus, findings were discussed only with literature information and other study findings with indirect similarities.

\section{References}

Akdoğan, B., \& Yalçın, S. B. (2018). Lise öğrencilerinin psikolojik dayanıklılık ve çatışma çözme davranışlarının öznel iyi oluşlarını yordaması [The prediction of subjective well-being by psychological resilience and conflict resolution behavior in high school students]. Mehmet Akif Ersoy Üniversitesi Eğitim Fakültesi Dergisi, 46, 174-197. https://doi.org/10.21764/maeuefd.370587

Ası1, E. (2013). Öğretmen adaylarının affetme özelliklerinin öz-duyarlık ve benlik saygısı açısından incelenmesi [Investigation of forgiving traits of prospective teachers in terms of self-compassion and self-esteem]. Unpublished master's thesis, Dokuz Eylül University Institute of Education Sciences, Izmir.

Brown, R. P. (2004). Vengeance is mine: Narcissism, vengeance, and the tendency to forgive. Journal of Research in Personality, 38, 576-584. https://doi.org/10.1016/j.jrp.2003.10.003

Bugay, A., \& Demir, A. (2011). Hataya ilişkin özelliklerin başkalarını affetmeyi yordaması [The features of transgression as predictors of forgiveness of others]. Turkish Psychological Counseling \& Guidance Journal, $4(35), 8-17$

Büyüköztürk, Ş. (2012). Bilimsel araştırma yöntemleri [Scientific research methods]. Ankara: Pegem Akademi.

Creswell, J. W. (2012). Educational research: Planning, conducting, and evaluating quantitative (1st ed.). Upper Saddle River, New Jersey: Prentice Hall.

Deutsch, M. (1973). The resolution of conflict. New Haven and London: Yale University Pres.

Enright, R. D., \& The Human Development Study Group. (1996). Counseling within the forgiveness triad: On forgiving, receiving forgiveness, and self-forgiveness. Counseling and Values, 40(2), 107-126. https://doi.org/10.1002/j.2161-007X.1996.tb00844.x

İkiz, F. E., \& Çatal, U. (2019). Öğretmen adaylarının çatışma eylem stillerinin duygusal öz-yeterlik düzeylerine göre incelenmesi [The investigation of prospective teachers' conflict action style according to the levels of their emotional self-efficacy]. Turkish Studies, 14(4), 2361-2382. https://doi.org/10.29228/TurkishStudies.23415

Harris, A. H., Luskin, F., Norman, S. B., Standard, S., Bruning, J., Evans, S., \& Thoresen, C. E. (2006). Effects of a group forgiveness intervention on forgiveness, perceived stress, and trait-anger. Journal of Clinical Psychology, 62(6), 715-733. https://doi.org/10.1002/jclp.20264

Jandt, F. E., \& Pedersen, P. B. (1996). Constructive conflict management: Asia-Pacific cases. Sage Publications. https://doi.org/10.4135/9781483327532

Johnson, D. W., \& Johnson, F. P. (2003). Joining together. New York: Pearson Education Inc.

Kağıtçıbaşı, Ç. (1996). Özerk-ilişkisel benlik: Yeni bir sentez. [Autonomous-relational self: A new synthesis]. Türk Psikoloji Dergisi, 11, 36-44.

Kağıtçıbaşı, Ç. (2005). Autonomy and relatedness in cultural context: Implications for self and family. Journal of 
Cross-Cultural Psychology, 36(4), 403-422. https://doi.org/10.1177/0022022105275959

Kahneman, D. (1999). Objective happiness. In D. Kahneman, E. Diener, \& N. Schwarz (Eds.), Well-being: The foundations of hedonic psychology, 3-25.

Karadağ, E., \& Tosun, Ü. (2014). Çatışma eylem stilleri ölçeği (ÇESÖ): Türkçe’ye uyarlanması dil geçerliği ve ön psikometrik incelemesi [The adaptation of conflict activity styles inventory (CASI) to Turkish language, language validity \& pre-psychometric investigation]. Psikoloji Çalışmaları Dergisi 34(1), 45-69.

Karip, E. (2013). Çatışma yönetimi [Managment of conflict]. Ankara: Pegem Akademi.

Karremans, J. C., \& Van Lange, P. A. M. (2004). Back to caring after being hurt: The role of forgiveness. European Journal of Social Psychology, 34(2), 207-227. https://doi.org/10.1002/ejsp.192

Kaya, K. S. (2019). Kişilerarası ilişkilerde affetme ölçeği: Geçerlik ve güvenirlik çalışması [The scale of forgiveness on interpersonal relationships: A validity and reliability study]. Elementary Education Online, 18(3), 1244-1259. https://doi.org/10.17051/ilkonline.2019.611538

Keyes, C. L. M., Shmotkin, D., \& Ryff, C. D. (2002). Optimizing well-being: The empirical encounter of two traditions. Journal of Personality and Social Psychology, 82(6), 1007-1022. https://doi.org/10.1037/0022-3514.82.6.1007

McCullough, M. E., Pargament, K. I., \& Thoresen, C. E. (2000). The psychology of forgiveness: History, conceptual issues, and overview. In M. E. McCullough, K.I. Pargament \& C. E. Thoresen (Eds.), Forgiveness: Theory, research, and practice. New York: The Guilford Press. https://doi.org/10.1037/0022-3514.73.2.321

McCullough, M. E., Worthington, E. L., \& Rachal, K. C. (1997). Interpersonal forgiving in close relationships. Journal of Personality and Social Psychology, 73(2), 321-336.

Matsumoto, D. (2009). The Cambridge dictionary of psychology. United Kingdom: Cambridge University Press.

Ryff, C. D. (1989). Happiness is everything or is it? Explorations on the meaning of psychological well-being. Journal of Personality and Social Psychology, 57(6), 1069-1081. https://doi.org/10.1037/0022-3514.57.6.1069

Ryff, C. D., \& Keyes, C. L. M. (1995). The structure of psychological well-being revisited. Journal of Personality and Social Psychology, 69(4), 719-727. https://doi.org/10.1037/0022-3514.69.4.719

Ryff, C. D., \& Singer B. (2008). Know thyself and become what you are: A eudaimonic approach to psychological well-being. Journal of Happiness Studies, 9, 13-39. https://doi.org/10.1007/s10902-006-9019-0

Öksüz, Y., \& Öztürk, B. M. (2016). Öğretmen adaylarının çatışma eylem stilleri ile kültürlerarası duyarlılık düzeyleri arasındaki ilişki [The relationship between pre-service teachers' conflict activity styles and intercultural sensitivity]. Manas Sosyal Araştırmalar Dergisi, 5(4), 1-12.

Özdemir, Y. (2012). Examination of adolescent's subjective well- being in terms of autonomous, relational and autonomous-relational self-construals. Turkish Psychological Counseling and Guidance Journal, 4(38), 188-198.

Rusbult, C. E., \& Zembrodt, I. M. (1983). Responses to dissatisfaction in romantic involvements: A multidimensional scaling analysis. Journal of Experimental Social Psychology, 19, 274-293. https://doi.org/10.1016/0022-1031(83)90042-2

Ryan R. M., \& Deci, E. L. (2001). On happiness and human potentials: A review of research on hedonic and eudaimonic well-being. Annual Review of Psychology, 52, 141-166. https://doi.org/10.1146/annurev.psych.52.1.141

Ryff, C. D., \& Keyes C. L. M (1995). The structure of psychological well-being revisited. Journal of Personality and Social Psychology, 69(4), 719-727. https://doi.org/10.1037/0022-3514.69.4.719

Sarıçam, H., \& Akın, A. (2013). Affedicilik ölçeğinin Türkçe uyarlaması: Geçerlik ve güvenirlik çalışması [The adaptation of forgivingness scale into Turkish: a validity and reliability study]. Hasan Ali Yücel Eğitim Fakültesi Dergisi, 19, 37-46.

Söner, O., \& Yılmaz, O. (2018). Lise öğrencilerinin sosyal medya bağımlılığı ve psikolojik iyi oluş düzeyleri arasındaki ilişki [The relationship between social media dependency and psychological well-being levels of high school students]. Ufuk Üniversitesi Sosyal Bilimler Enstitüsü Dergisi, 13, 59-73.

Telef, B. B. (2013). Psikolojik iyi oluş ölçeği: Türkçeye uyarlama, geçerlik ve güvenirlik çalışması [The adaptation 
of psychological well-being into Turkish: a validity and reliability study]. Hacettepe University Journal of Education, 28(3), 374-384.

Thomas, K. W. (1976). Conflict and conflict management. In M. D. Dunnette (Ed.), Handbook of industrial and organizational psychology. Chicago: Rand McNally, 889-935.

Toussaint, L. L., Williams, D. R., Musick, M. A., \& Everson-Rose, S. A. (2008). Why forgiveness may protect against depression: Hopelessness as an explanatory mechanism. Personality and Mental Health, 2(2), 89-103. https://doi.org/10.1002/pmh.35

Wall, J. A., \& Callister, R. R. (1995). Conflict and its management. Journal of Management, 21(3), 515-558. https://doi.org/10.1177/014920639502100306

Yeh, K. H., \& Yang, Y. J. (2006). Construct validation of individuating and relating autonomy orientations in culturally Chinese adolescents. Asian Journal of Social Psychology, 9, 148-160. https://doi.org/10.1111/j.1467-839X.2006.00192.x

\section{Copyrights}

Copyright for this article is retained by the author(s), with first publication rights granted to the journal.

This is an open-access article distributed under the terms and conditions of the Creative Commons Attribution license (http://creativecommons.org/licenses/by/4.0/). 